\title{
LEGALISASI PENCABUTAN HAK POLITIK TERPIDANA TINDAK PIDANA KORUPSI UNTUK SELAMANYA
}

\author{
Tomson Situmeang \\ Sharon Pauli Sanada, Monalisa Nirwana Simanullang, Erika Michelle Angel \\ Email: tomson.situmeang@uki.ac.id \\ Universitas Kristen Indonesia, \\ Jakarta, Indonesia
}

\begin{abstract}
The country will progress if it successfully carries out the development of 2 (two) main factors, namely: "natural resources" and "human resources". Indonesia, with its abundant natural resources, is not even among the 10 (ten) highest income countries in Asia. This is due to the corrupt behavior of officials (state) in Indonesia by abusing the position or position obtained, one of them through the political process. Such people are no longer fit to return to political office, so their political rights must be revoked. Revocation of political rights is indeed accepted and recognized in Indonesian law, namely in the provisions of Article 28J of the 1945 Constitution and Article 73 of the Human Rights Law which mandates limitations to the provisions of the law. In addition, there are provisions in Article 10 of the Criminal Code jo. Article 35 of the Criminal Code jo. Article 38 of the Criminal Code jo. Article 18 Corruption Law can be carried out by a judge's decision. Therefore, revocation of the political rights of convicts of criminal acts of corruption can be done forever, provided that they are stipulated in the provisions of the law by including corruption in the category of disgraceful acts.
\end{abstract}

\section{Keywords: pencabutan hak politik, tindak pidana korupsi, perbuatan tercela}

\section{Pendahuluan}

Kemajuan suatu negara sangat ditentukan oleh keberhasilannya dalam melaksanakan pembangunan. Keberhasilan pembangunan ditentukan oleh berbagai faktor ${ }^{3}$, diantaranya yang terpenting adalah "sumber daya alam" dan "sumber daya manusia". Sumber daya manusia yaitu: orang yang terlibat dalam perencanaan, pelaksanaan dan pengawasan pembangunan. Tetapi menjadi ironi, Indonesia dengan kekayaan sumber daya alam melimpah, justru tidak masuk salah satu

\footnotetext{
${ }^{1}$ Dosen Tetap FH UKI selaku Pembimbing Tim Debat FH UKI dalam Kompetisi Debat Konstitusi Mahasiswa Antar Perguruan Tinggi Se-Indonesia Tahun 2017 yang diadakan oleh Mahkamah Konstitusi RI.

${ }^{2}$ Mahasiswa Peserta Tim Debat FH UKI dalam Kompetisi Debat Konstitusi Mahasiswa Antar Perguruan Tinggi Se-Indonesia Tahun 2017 yang diadakan oleh Mahkamah Konstitusi RI.

${ }^{3}$ Ahmad Dian, 7 Faktor Pembangunan Ekonomi Suatu Negara, (lihat situs: http://dosenekonomi.com/ilmu-ekonomi/publik/ faktorpembangunan-ekonomi, dimuat tanggal 9 Februari 2017), band.: Andi Pujianto, 4 Faktor yang Memengaruhi Pertumbuhan dan Pembangunan Ekonomi, (lihat situs: http://www. ekonomikontekstual.com/2014/04/4-faktor-yang-memengaruhipertumbuhan-dan-pembangunan-ekonomi.html, dimuat tanggal 14 April 2014).
}

negara, di antara 10 negara dengan pendapatan tertinggi di Asia ${ }^{4}$.

Hal tersebut bukan karena tingkat pengetahuan dan intelektual yang rendah, tetapi karena rendahnya kualitas moral $^{5}$ dan kepribadian manusianya yang terlibat dalam perencanaan, pelaksanaan dan pengawasan pembangunan. Rendahnya kualitas moral dan kepribadian penyelenggara negara telah membuat rendahnya tingkat kejujurannya, sehingga cenderung berperilaku "koruptif". Tak heran, jika korupsi di Indonesia menjadi "momok",

\footnotetext{
${ }^{4} 10$ Negara dengan Pendapatan Tertinggi di Asia, lihat situs: http://bisnis.liputan6.com/read/2469051/10-negara-denganpendapatan-tertinggi-di-asia, dimuat tanggal 28 Maret 2016.

${ }^{5}$ Sigid Suseno, Pungli/ Gratifikasi/ Penyalahgunaan Jabatan $=$ Korupsi, (disampaikan dalam Bahan Pendidikan Anti Korupsi:Bandung, 2016), hal. 10.

6 "koruptif" adalah sifat takut berkorban dan menyebabkan mereka mudah ditaklukan musuh (lihat situs: http://kbbi.web.id/ koruptif)

7 "momok" adalah sesuatu yang menakutkan karena ganas, berbahaya, dan sebagainya (lihat situs: http://kbbi.web.id/ momok).
} 
bahkan menjadi penyakit sosial ("patologi social") yang sangat berbahaya dan mengancam berbagai aspek kehidupan berbangsa dan bernegara.

Korupsi tak hanya mengakibatkan kerugian materiil keuangan negara, tetapi telah menyalahgunakan kedudukan atau jabatan yang diperoleh, salah satunya melalui proses politik, untuk memperkaya diri sendiri atau orang lain yang merupakan kroninya ${ }^{9}$. Hal itu merupakan cerminan rendahnya moral pejabat negara yang memperoleh kedudukan atau jabatan dari proses politik. Kecenderungan perilaku koruptif, apalagi dengan skala besar, lebih banyak dilakukan oleh orang yang menduduki "jabatan politis", yaitu diperoleh melalui kontestasi politik, baik pemilihan umum anggota DPR RI, MPR RI, DPD RI dan DPRD maupun pemilihan kepala daerah provinsi ataupun kabupaten/kota.

Karena korupsi lebih banyak dilakukan oleh pejabat negara yang menduduki jabatan politis, maka pelakunya dapat dianggap adalah orang yang telah rusak moralnya, sehingga orang yang demikian tidak pantas lagi untuk kembali menduduki jabatan politis karena akan berpotensi untuk mengulangi perbuatannya.

\section{Permasalahan}

1. Bagaimana aturan hukum tentang Hak Politik dan Pencabutan Hak Politik yang berlaku dan diterima di Indonesia?

2. Bagaimana me-legal-kan Pencabutan Hak Politik Terpidana Tindak Pidana Korupsi untuk selamanya?

\section{Tujuan Penulisan}

1. Untuk mengetahui aturan hukum tentang Hak Politik dan Pencabutan Hak Politik yang berlaku dan diterima di Indonesia.

2. Untuk memberikan alasan yang dapat me-legalkan Pencabutan Hak Politik Terpidana Tindak Pidana Korupsi untuk selamanya.

\section{Korupsi dan Tindak Pidana Korupsi}

Kata korupsi berasal dari kata "corruptio", yang berarti kerusakan ${ }^{10}$. Menurut Fockema Andrea ${ }^{11}$,kata

\footnotetext{
8 "patologi sosial" adalah ilmu yang mempelajari tentang penyakit masyarakat (lihat situs: http://kbbi.web.id/patologi).

${ }^{9}$ Contoh Kasus yang melibatkan kroni-kroni Pejabat Negara adalah Kasus Korupsi "Wisma Atlet" dan Kasus Korupsi "Hambalang" yang melibatkan banyak kader-kader Partai Politik.

${ }^{10}$ Sudarto, Hukum dan Hukum Pidana, (Bandung: Alumni, 2007), hal.114.

${ }^{11}$ Kamus Hukum, Fockema Andreae, (Bandung: Bina Cipta, 1983), huruf c. Terjemahan Bina Cipta, dalam: Andi Hamzah, Pemberantasan Korupsi: Melalui Hukum Pidana Nasional dan Internasional, (Jakarta: Rajawali Pers, 2014), hal. 4.
}

korupsi berasal dari bahasa Latin "corruptus" atau "corruptio", atau "corrumpere", yang dalam bahasa Inggris dan Prancis disebut "corruption" dan dalam bahasa Belanda, yaitu "corruptie" (korruptie), yang diadopsi ke bahasa Indonesia, yaitu "korupsi". Kata korupsi dalam KBBI disebutkan: "Korupsi ialah perbuatan yang buruk seperti penggelapan uang, penerimaan uang sogok dan sebagainya"12. Sigid Suseno $^{13}$, secaraharafiahmenyatakan"Korupsiadalah kebusukan, keburukan, kebejatan, ketidakjujuran, dapat disuap, tidak bermoral, penyimpangan dari kesucian".

Tindak pidana (perbuatan) korupsi merupakan ancaman terhadap prinsip-prinsip demokrasi, yang menjunjung tinggi transparansi, akuntabilitas dan integritas karena merupakan tindak pidana yang bersifat sistematik dan merugikan pembangunan berkelanjutan. Langkah pencegahan dan pemberantasannya harus bersifat menyeluruh, sistematis dan berkesinambungan, dalam semua tingkat yang dilakukan secara efisien dan efektif ${ }^{14}$.

\section{Aturan Hukum Hak Politik dan Pencabutan Hak Politik}

Salah satu Hak Asasi Manusia (HAM) adalah hak politik, sebagaimana termuat dalam Pasal 25 International Covenant On Civil And Political Rights (ICCPR 1966) ${ }^{15}$, yang menyebutkan: setiap warga negara harus mempunyai hak dan kesempatan yang sama untuk tanpa pembedaan apapun dan tanpa pembatasan yang tidak wajar untuk berpartisipasi dalam menjalankan segala urusan umum baik secara langsung maupun melalui wakil-wakil yang dipilih secara bebas, selanjutnya untuk memilih dan dipilih pada pemilihan berkala yang bebas dan dengan hak pilih yang sama dan universal serta diadakan melalui pengeluaran suara tertulis dan rahasia yang menjamin

\footnotetext{
${ }^{12}$ Poerwadarminta, Kamus Umum Bahasa Indonesia, 1976, dalam: Andi Hamzah, Pemberantasan Korupsi: Melalui Hukum Pidana Nasional dan Internasional, (Jakarta: Rajawali Pers, 2014), hal. 5.

${ }^{13}$ Ibid, Sigid Suseno, hal. 2.

${ }^{14}$ Republik Indonesia, Undang-Undang Nomor 7 Tahun 2006 tentang Pengesahan United Nation Convention Against Corruption, 2003 (Konvensi PBB Anti Korupsi, 2003), Penjelasan Bagian I Umum, Paragraf Pertama, (Lembaran Negara RI Tahun 2006 No. 32, Tambahan Lembaran Negara RI No. 4620).

${ }^{15}$ International Convenant on Civil and Political Rights articles 25: (a) Every citizen shall have the right and the opportunity, without any of the distinctions mentioned in article 2 and without unreasonable restrictions, (b) to vote and to be elected at genuine periodic elections which shall be by universal and equal suffrage and shall be held by secret ballot, guaranteeing the free expression of the will of the electors, (c) to have access, on general terms of equality, to public service in his country."
} 
para pemilih untuk menyatakan kehendak mereka dengan bebas, dan untuk mendapatkan pelayanan umum di negaranya sendiri pada umumnya atas dasar persamaan.

ICCPR mengklasifikasikan hak sipil dan politik ke dalam dua bagian ${ }^{16}$, yaitu hak absolut ${ }^{17}$ dan hak yang boleh dikurangi ${ }^{18}$. Deklarasi Universal HAM juga memberikan pengertian dan batasan hak politik yang dimiliki oleh setiap warga negara, yaitu:

1) Setiap orang berhak turut serta dalam pemerintahan negaranya, secara langsung atau melalui wakil-wakil yang dipilih dengan bebas.

2) Setiap orang berhak atas kesempatan yang sama untuk diangkat dalam jabatan pemerintahan negaranya.

3) Kehendak rakyat harus menjadi dasar kekuasaan pemerintah; kehendak ini harus dinyatakan dalam pemilihan umum yang dilaksanakan secara berkala dan murni, dengan hak pilih yang bersifat umum dan sederajat, dengan pemungutan suara secara rahasia ataupun dengan prosedur lain yang menjamin kebebasan memberikan suara.

Maka setiap warga negara mempunyai hak yang sama dan implementasi hak dan kewajiban punharus bersama-sama ${ }^{19}$. HAM dalam hukum Indonesia dapat dibatasi bahkan dicabut ${ }^{20}$, dimana pembatasan

\footnotetext{
${ }^{16}$ Muhardi Hasan dan Estika Sari, Hak Sipil dan Politik, Demokrasi, Vol. IV No.1 th. 2005, hal. 93-101 (lihat situs: http://ejournal. unp.ac.id/index.php/jd/article/viewFile/1001/843).

${ }^{17}$ hak-hak absolut adalah hak yang harus ditegakkan dan dihormati dalam keadaan apapun, seperti hak untuk hidup, hak untuk bebas dari penyiksaan, hak bebas dari perbudakan, hak bebas dari penahanan karena gagal memenuhi perjanjian (hutang), hak bebas dari pemidanaan yang berlaku surut, hak atas kebebasan berpikir dan sebagainya, Ibid, hal. 97.

${ }^{18}$ hak-hak yang boleh dikurangi pemenuhannya oleh negara seperti hak atas kebebasan berkumpul secara damai, hak atas kebebasan menyatakan pendapat atau berekspresi, hak atas kebebasan berserikat, hak untuk mendapatkan dan memberi informasi dan lain sebagainya, Ibid, hal. 97.

19 A.Gunawan Setiardja, Hak-Hak Asasi Manusia Berdasarkan Ideologi Pancasila, (Yogyakarta: Kanisius, 1993), hal. 117.

${ }^{20}$ Republik Indonesia, Undang-Undang Nomor 39 Tahun 1999 tentang Hak Asasi Manusia, (Lembaran Negara RI Tahun 1999 No. 165, Tambahan Lembaran Negara RI No. 3886), Pasal 73, berbunyi: "hak dan kebebasan yang diatur dalam Undang-undang ini hanya dapat dibatasi oleh dan berdasarkan Undang-undang, semata-mata untuk menjamin pengakuan dan penghormatan terhadap hak asasi manusia serta kebebasan dasar orang lain, kesusilaan, ketertiban umum, dan kepentingan bangsa”, band.: Pasal 28J ayat (2) UUD 1945, berbunyi: "dalam menjalankan hak dan kebebasannya, setiap orang wajib tunduk kepada pembatasan yang ditetapkan dengan undang-undang dengan maksud sematamata untuk menjamin pengakuan serta penghormatan atas hak dan kebebasan orang lain dan untuk memenuhi tuntutan yang adil sesuai dengan pertimbangan moral, nilai-nilai agama, keamanan, dan ketertiban umum dalam suatu masyarakat demokratis".
}

atau pencabutan HAM tersebut harus berdasarkan undang-undang untuk tujuan menjamin pengakuan dan penghormatan HAM serta kebebasan dasar orang lain, kesusilaan, ketertiban umum, dan kepentingan bangsa. Hak yang dapat dicabut adalah hak politik, sebagaimana ketentuan Pasal 10 KUHPidana ${ }^{21}$ jo. Pasal 35 ayat (1) KUHPidana ${ }^{22}$. Hanya saja pencabutan hak politik tersebut masih dibatasi dengan waktu tertentu, kecuali terhadap terpidana mati dan terpidana penjara seumur hidup ${ }^{23}$.

Andi Hamzah (2008:203), mengutip HB Vos (Leerboek van het Netherlandse Strafrecht), mengatakan pidana pencabutan hak-hak tertentu berada di ranah kehormatan, yang membedakannya dari pidana hilang kemerdekaan, dimana pencabutan hak tertentu tidak otomatis karena harus ditetapkan lewat putusan hakim dan tidak berlaku seumur hidup tetapi menurut jangka waktu menurut undang-undang dengan suatu putusan hakim. Padahal pencabutan hak politik, khususnya hak untuk dipilih sebagai pejabat publik adalah bentuk hukuman terhadap orang-orang yang menyalahgunakan haknya ${ }^{24}$ dan tidak amanah dalam memegang jabatan publik. Selain itu, agar yang bersangkutan tidak bisa lagi menyalahgunakan wewenangnya.

Dalam Perspektif HAM di Indonesia, pencabutan HAM memang dibenarkan, sesuai ketentuan Pasal 28J

\footnotetext{
${ }^{21}$ Pasal 10 KUHPidana, berbunyi:

a. Pidana Pokok, terdiri dari: Pidana Mati; Pidana Penjara; Kurungan; dan Denda.

b. Pidana Tambahan, terdiri dari: Pencabutan Hak-Hak Tertentu; Perampasan Barang-Barang Tertentu; dan Pengumuman Putusan Hakim

${ }^{22}$ Pasal 35 ayat (1) KUHPidana, berbunyi:

Hak-hak terpidana yang dengan putusan hakim dapat dicabut dalam hal-hal yang ditentukan dalam kitab undang-undang ini atau dalam aturan umum lainnya ialah: -hak memegang jabatan pada umumnya atau jabatan tertentu; -hak memasuki angkatan bersenjata; -hak memilih dan dipilih dalam pemilihan yang dadakan berdasarkan aturan-aturan umum; -hak menjadi penasihat hukum atau pengurus atas penetapan pengadilan, hak menjadi wali pengawas, pengampu atau pengampu pengawas atas orang yang bukan anak sendiri; -hak menjalankan kekuasaan bapak, menjalankan perwakilan atau pengampu atas anak sendiri; dan -hak menjalankan mata pencarian tertentu.

${ }^{23}$ Pasal 38 ayat (1) KUHPidana, berbunyi:

Jika dilakukan pencabutan hak, hakim menentukan lamanya pencabutan sebagai berikut:

1. dalam hal pidana mati atau pidana penjara seumur hidup, lamanya pencabutan seumur hidup;

2. dalam hal pidana penjara untuk waktu tertentu atau pidana kurungan, lamanya pencabutan paling sedikit dua tahun dan paling banyak lima tahun lebih lama dari pidana pokoknya;

3. dalam hal pidana denda, lamanya pencabutan paling sedikitdua tahun dan paling banyak lima tahun.

${ }^{24}$ P.A.F.Lamintang dan Theo Lamintang, Hukum Penitensier Indonesia, (Jakarta: Sinar Grafika,2010), hal. 87.
} 
ayat (2) Undang-Undang Dasar $1945^{25}$ (UUD 1945) dan ketentuan Pasal 73 UU HAM ${ }^{26}$. Pencabutan hak politik sebagai salah satu HAM di Indonesia harus dengan putusan hakim, sesuai ketentuan Pasal 10 jo. Pasal 35 KUHPidana. Pencabutan tersebut, seolah-olah hanya bagi pelaku kejahatan yang diatur dalam KUHPidana tersebut. Namun berdasarkan ketentuan Pasal 18 UU Tipikor ${ }^{27}$, pencabutan tersebut juga berlaku bagi pelaku tindak pidana korupsi, sehingga juga masih dibatasi dengan limitasi waktu, sebagaimana ketentuan Pasal 38 KUHPidana. Mencermati ketentuan Pasal 10 jo. Pasal 35 jo. Pasal 38 KUHPidana jo. Pasal 18 UU Tipikor, seolah tidak sejalan dengan ketentuan Pasal 28J ayat (2) UUD 1945 dan ketentuan Pasal 73 UU HAM, karena menurut UUD 1945 dan UU HAM, pencabutan HAM hanya dapat dilakukan dengan ketentuan undang-undang, bukan dengan putusan hakim. Sedangkan ketentuan Pasal 10 jo. Pasal 35 jo. Pasal 38 KUHPidana jo. Pasal 18 UU Tipikor, pencabutan hak politik merupakan kewenangan hakim.

Pencabutan hak politik mantan narapidana, secara umum akan menimbulkan polemik, dengan alasan melanggar HAM dan tidak sejalan dengan tujuan pemasyarakatan, dimana pemidanaan bukan bentuk pembalasan, melainkan untuk merehabilitasi terpidana agar bisa kembali ke masyarakat sebagai warga yang baik dan bertanggung jawab setelah menyadari kesalahan dan memperbaiki dirinya ${ }^{28}$. Selain itu, hak politik dianggap sebagai hak absolut yang tidak boleh dikurangi pemenuhannya oleh Negara, walau dalam keadaan darurat sekalipun. Padahal hak tersebut merupakan hak yang derogable

\footnotetext{
${ }^{25}$ Pasal 28J ayat (2) UUD 1945, berbunyi: "dalam menjalankan hak dan kebebasannya, setiap orang wajib tunduk kepada pembatasan yang ditetapkan dengan undang-undang dengan maksud sematamata untuk menjamin pengakuan serta penghormatan atas hak dan kebebasan orang lain dan untuk memenuhi tuntutan yang adil sesuai dengan pertimbangan moral, nilai-nilai agama, keamanan, dan ketertiban umum dalam suatu masyarakat demokratis".

${ }^{26}$ Pasal 73 Undang-Undang Nomor 39 Tahun 1999 tentang Hak Asasi Manusia, berbunyi: "hak dan kebebasan yang diatur dalam Undang-undang ini hanya dapat dibatasi oleh dan berdasarkan Undang-undang, semata-mata untuk menjamin pengakuan dan penghormatan terhadap hak asasi manusia serta kebebasan dasar orang lain, kesusilaan, ketertiban umum, dan kepentingan bangsa".

${ }^{27}$ Op.Cit, Republik Indonesia, Undang-Undang Nomor 20 Tahun 2001, Pasal 18 ayat (1), berbunyi: "selain pidana tambahan dimaksud dalam KUHPidana...dst...".

${ }^{28}$ Republik Indonesia, Undang-Undang Nomor 12 Tahun 1995 tentang Pemasyarakatan, Bagian Menimbang huruf c., (Lembaran Negara RI Tahun 1995 No. 77, Tambahan Lembaran Negara RI No. 3614).
}

rights ${ }^{29}$, yaitu hak yang boleh dikurangi atau dibatasi pemenuhannya oleh Negara.

Tetapi, pencabutan hak politik terpidana tindak pidana korupsi untuk selamanya dapat dilakukan, asalkan diatur dalam ketentuan UndangUndang, sebagaimana amanah ketentuan Pasal 28J ayat (2) UUD 1945 dan ketentuan Pasal 73 UU HAM, dengan menyatakan perbuatan korupsi sebagai perbuatan tercela. Jadi, pencabutan hak politik dapat dilakukan sebagai bentuk pengakuan dan penghormatan hak dan kebebasan orang lain, dengan kata lain hak politik dapat dibatasi melalui undangundang demi menjamin hak masyarakat yang diambil oleh koruptor ${ }^{30}$.

\section{Pencabutan Hak Politik Terpidana Tindak Pidana Korupsi Untuk Selamanya}

Pencabutan hak politik, khususnya hak untuk dipilih sebagai pejabat publik adalah bentuk hukuman terhadap orang yang dipilih yang menyalahgunakan kedudukan atau jabatan yang diperoleh dari proses politik, maka sudah seharusnya orang tersebut ("narapidana kasus tindak pidana korupsi") tidak lagi diberikan kesempatan untuk menduduki jabatan publik. Tetapi pencabutan hak politik masih dibatasi tenggang waktu tertentu, kecuali terhadap terpidana mati dan terpidana penjara seumur hidup. Sementara Undang-Undang tentang Pemberantasan Tindak Pidana Korupsi (UU Tipikor) di Indonesia ${ }^{31}$, hanya terdapat 1 (satu) pasal yang mengatur ancaman hukuman mati, yaitu Pasal 2 ayat (2) dan terdapat 4 (empat) pasal yang mengatur ancaman hukuman pidana penjara seumur hidup, yaitu Pasal 2 ayat (1), Pasal 3, Pasal 12 dan Pasal 12B ayat (2).

\footnotetext{
${ }^{29}$ Ifdhal Kasim (Editor), Hak Sipil dan Politik Esai-Esai Pilihan, (Jakarta: Lembaga Studi dan Advokasi Masyarakat (ELSAM), 2001), hal. 49, menyatakan: derogable rights adalah: (i) hak atas kebebasan berkumpul secara damai; (ii) hak atas kebebasan berserikat, termasuk membentuk dan mnjadi anggota serikat buruh; dan (iii) hak atas kebebasan menyatakan pendapat atau berekspresi, termasuk kebebasan mencari, menerima dan memberikan informasi dari segala gagasan tanpa memperhatikan batas (baik melalui lisan maupun tulisan).

${ }^{30}$ Vita Dwi Sakundiana, Pencabutan Hak Politik Bagi Koruptor, (lihat situs: https://safwaalmahyra.wordpress.com/2016/12/27/ pencabutan-hak-politik-bagi-koruptor/), dimuat tanggal 27 desember 2016

${ }^{31}$ Republik Indonesia, Undang-Undang Nomor 31 Tahun 1999 tentang Pemberantasan Tindak Pidana Korupsi, (Lembaran Negara RI Tahun 1999 No. 140, Tambahan Lembaran Negara RI No. 3874) jo. Undang-Undang Nomor 20 Tahun 2001 tentang Perubahan Atas Undang-Undang Nomor 31 Tahun 1999 tentang Pemberantasan Tindak Pidana Korupsi, (Lembaran Negara R Tahun 2001 No. 134, Tambahan Lembaran Negara RI No. 4150).
} 
Apabila ketentuan Pasal 35 KUHPidana dan Pasal 38 KUHPidana dihubungkan denganketentuan UU Tipikor dan Undang-Undang Nomor 39 Tahun 1999 tentang HAM (UU HAM), maka tidak menutup kemungkinan "narapidana kasus tindak pidana korupsi" kembali mengikuti kontestasi pemilihan untuk mendapatkan jabatan publik, dan membuka peluang untuk kembali menyalahgunakan kedudukan atau jabatannya.

Oleh karena itu, sudah seharusnya mantan "narapidana kasus tindak pidana korupsi" dicabut hak politiknya untuk selamanya, dengan mengaturnya dalam ketentuan undang-undang, dimana perbuatan korupsi adalah bagian dari perbuatan tercela, sebagaimana ketentuan Pasal 7 ayat (2) huruf i Undang-Undang Nomor 10 Tahun $2016^{32}$, yang penjelasannya yang menyatakan: "yang dimaksud dengan "melakukan perbuatan tercela" antara lain judi, mabuk, pemakai/pengedar narkotika, dan berzina, serta perbuatan melanggar kesusilaan lainnya".

Perbuatan korupsi sebagai perbuatan tercela, jika diatur dalam suatu ketentuan Undang-Undang, ternyata sudah memenuhi landasan filosofis, landasan sosiologis dan landasan yuridis.

\section{Landasan Filosofis}

\section{a. Pandangan Pancasila}

Bangsa Indonesia adalah bangsa dengan Ideologi Pancasila. Menurut Ketua KPK (ketika itu Antasari Azhar), Pancasila sesunggguhnya merupakan sumber nilai anti korupsi ${ }^{33}$. Oleh karena itu, untuk melihat indikator perbuatan korupsi sebagai perbuatan tercela dapat dilihat dari sudat pandang Pancasila, melalui butir-butir Pancasila. Perbuatan korupsibertentangan dengan butir kedua Sila I Pancasila, yang berbunyi: "manusia Indonesia percaya dan taqwa terhadap Tuhan Yang Maha Esa, sesuai dengan agama dan kepercayaannya masing-masing menurut dasar kemanusiaan yang adil dan beradab". Butir tersebut menyatakan "menurut dasar kemanusiaan yang adil dan beradab", yang merupakan Sila II Pancasila.

\footnotetext{
${ }^{32}$ Republik Indonesia, Undang-Undang Nomor 10 Tahun 2016 tentang Perubahan Kedua Atas Undang-Undang Nomor 1 Tahun 2015 tentang Penetapan Peraturan Pemerintah Pengganti Undang-Undang Nomor 1 Tahun 2014 tentang Pemilihan Gubernur, Bupati, Dan Walikota Menjadi Undang-Undang, (Lembaran Negara RI Tahun 2016 No. 130, Tambahan Lembaran Negara RI No. 5898).

${ }^{33}$ KPK: Pancasila Sumber Nilai Anti Korupsi (lihat situs: http:// www.antaranews.com/print/104149/kpk-pancasila-sumber-nilaianti-korupsi).
}

Butir-butir Sila II Pancasila merupakan cermin "anti korupsi", yaitu butir ke-5, ke-6 dan ke- 8 dengan alasan bahwa perbuatan korupsi tidak menggambarkan perbuatan yang "mengembangkan sikap tidak semena-mena terhadap orang lain", "menjunjung tinggi nilai-nilai kemanusiaan", dan sikap "berani membela kebenaran dan keadilan".

Perbuatan korupsi tidak mencerminkan sikap dan perbuatan yang "menempatkan kepentingan bangsa dan negara sebagai kepentingan bersama di atas kepentingan pribadi dan golongan", "rela berkorban untuk kepentingan negara dan bangsa apabila diperlukan" dan sikap "cinta kepada tanah air dan bangsa", sebagaimana butir ke-1, ke-2 dan ke-3 Sila III Pancasila. Selain itu, juga tidak mencerminkan nilai-nilai yang terkandung dalam butir-butir Sila V Pancasila, yaitu butir ke-1: “mengembangkan perbuatan yang luhur, yang mencerminkan sikapdan suasana kekeluargaan dan kegotongroyongan", butir ke-2: "mengembangkan sikap adil terhadap sesama", dan butir ke-3: "menjaga keseimbangan antara hak dan kewajiban", serta butir ke-4: "menghormati hak orang lain".

\section{b. Pandangan Agama}

Dalam hal ini, penulis hanya akan menguraikan sedikit dari sudut pandang agama Islam dan agama Kristen.

(1) Agama Islam - Agama Islam sangat menjunjung tinggi pemeliharaan akan kesucian, baik lahir maupun bathin, yang menghendaki agar manusia dalam melakukan sesuatu harus sesuai fitrahnya, yang telah ditentukan dalam Al-Quran sebagai sumber hukum tertinggi ${ }^{34}$. Dalam pandangan agama Islam, perbuatan korupsi meliputi beberapa dimensi, diantaranya: risywah atau suap, saraqah atau pencurian, al gasysy atau penipuan, dan khianat atau penghianatan. Menurut QS. Al Maidah: 38 ${ }^{35}$, hukuman bagi pencurian (saraqah) adalah potong tangan dan dalam QS. Al-Anfal: 2736, dilarang untuk menghianati amanah yang diberikan. Karena

\footnotetext{
${ }^{34}$ Hammady Ghitsny, Pandangan Agama terhadap Korupsi, (lihat situs: http://www.kompasiana.com/hammady/pandangan-agamaterhadap-korupsi_58b28624147b61fa10260673), dimuat tanggal 26 Februari 2017.

${ }^{35}$ QS. Al- Maidah: 38, menyatakan: "Laki-laki yang mencuri dan perempuan yang mencuri, potonglah tangan keduanya (sebagai) pembalasan bagi apa yang mereka kerjakan dan sebagai siksaan dari Allah. Dan Allah Maha Perkasa lagi Maha Bijaksana".

${ }^{36}$ QS. Al-Anfal: 27, menyatakan: "Hai orang-orang yang beriman, janganlah kamu mengkhianati Allah dan Rasul (Muhammad) dan (juga) janganlah kamu mengkhianati amanat-amanat yang dipercayakan kepadamu, sedang kamu mengetahui".
} 
perbuatan khianat adalah perbuatan yang sangat dibenci Allah dan merupakan sifat tercela ${ }^{37}$, sehingga Nabi Muhammad SAW dalam sebuah hadisnya menyatakan bahwa "dilaknat oleh Allah bagi pemberi suap dan penerima suap" ${ }^{38}$.

(2) Agama Kristen - Dalam Alkitab tidak akan ditemukan kata "korupsi", tetapi melihat penjabarankorupsidanperbuatankorupsidiatas, maka pebuatan korupsi dimaknai sebagai perbuatan jahat yang mempunyai dimensi yang cukup luas, sehingga sulit untuk mendefenisikannya ${ }^{39}$. Makna dasar kejahatan dalam Alkitab adalah "merusak" atau "meremukkan" yang akibatnya tidak menyenangkan, merugikan sesama, tidak enak dan menjijikkan ${ }^{40}$. Sebab itulah Allah tidak berkenan dan melarang tindakan penyuapan, sebagaimana dituliskan dalam Kitab Keluaran 23 ayat 8, yang berbunyi: "Suap janganlah kau terima, sebab suap membuat buta mata orangorang yang melihat dan memutarbalikkan perkara orang-orang yang benar".

\section{Landasan Sosiologis}

Dalam lingkungan sosial, perbuatan korupsi dinyatakan sebagai perbuatan tercela, yang merusak tatanan kehidupan bermasyarakat dan bernegara karena memperkaya diri sendiri dengan tidak $\mathrm{sah}^{41}$. Perbuatan korupsi dipandang sebagai "perbuatan tercela" karena melanggar kesusilaan dan kepentingan umum dan tidak sesuai dengan rasa keadilan atau norma-norma kehidupan sosial dalam masyarakat. Pelaku korupsi yang telah merugikan masyarakat luas dengan merampas hak-hak sosial masyarakat, maka pencabutan hak politik menjadi deterrent effect ${ }^{42}$ baginya (narapidana tindak pidana korupsi).

\footnotetext{
${ }^{37}$ Soumy Mubarok dan Lismanto, Korupsi sebagai Perbuatan Khiyanat dalam Hukum Islam, (lihat situs: http://www.islamcendekia. com/2014/01/korupsi-sebagai-perbuatan-khiyanat-dalam-hukumislam.html? $m=1$ ), dimuat 21 Januari 2014.

${ }^{38}$ Hamdan Zoelva, Fenomena Korupsi di Indonesia dari Sudut Pandang Filsafat Ilmu, (lihat situs: https://hamdanzoelva. wordpress.com/2008/08/11/fenomena-korupsi-dari-sudutpandang-filsafat-ilmu/).

${ }^{39}$ Yon Maryono, Dimensi Korupsi dalam Alkitab, (lihat situs: http://artikel.sabda.org/dimensi_korupsi_dalam_alkitab).

${ }^{40}$ Ibid.

${ }^{41}$ Ruslan Renggong, Hukum Pidana Khusus: Memahami Delik-delik di luar KUHP, (Jakarta: Prenadamedia Group, 2016), hal. 62-63.

${ }^{42} \mathrm{~A}$ deterrent is something that prevents people from doing something by making them afraid of what will happen to them if they do it (lihat situs: http://dictionary.reverso.net/englishcobuild/deterrent\%20effect), band.: "deterrent effect" adalah efek yang membuat seseorang mengurungkan niatnya melakukan sesuatu karena takut akan ganjaran yang bakal ia terima (lihat situs: $\quad$ https://rubrikbahasa.wordpress.com/2010/09/24/ menggentarkan-malaysia/).
}

Masyarakat menolak dan mengutuk keras perbuatan korupsi, sebagaimana KADIN mengadakan gerakan moral untuk memerangi praktik suap sebagai bagian dari korupsi yang ditujukan kepada seluruh dunia usaha dengan mengadakan kampanye nasional antisuap dan gerakan nasional antisuap. Sebelumnya NUbekerjasamadengan Muhammadiyah telah melakukan gerakan moral untuk memberantas korupsi ${ }^{43}$. Itu artinya perbuatan korupsi adalah perbuatan yang menciderai rasa keadilan masyarakat dan dianggap sebagai perbuatan tercela.

Hamdan Zoelva, mantan Ketua Mahkamah Konstitusi, dalam desertasi-doktornya, menyatakan "bahwa perbuatan tercela erat kaitannya dengan pelanggaran nilai-nilai agama, moral maupun adat".

\section{Landasan Yuridis}

Tindak Pidana Korupsi, dalam penjelasan Undang-Undang RI No. 7 Tahun $2006^{44}$, menyatakan bahwa perbuatan korupsi merupakan ancaman terhadap prinsip-prinsip demokrasi, yang menjunjung tinggi transparansi, akuntabilitas dan integritas karena merupakan tindak pidana yang bersifat sistematik dan merugikan pembangunan berkelanjutan, sehingga memerlukan langkah pencegahan dan pemberantasan yang bersifat menyeluruh, sistematis dan berkesinambungan yang harus dilakukan secara efisien dan efektif. Alasan perubahan UU Tipikor ${ }^{45}$, menyatakan: "tindak pidana korupsi merupakan pelanggaran terhadap hak-hak sosial dan ekonomi masyarakat secara luas, sehingga tindak pidana korupsi perlu digolongkan sebagai kejahatan yang pemberantasannya harus dilakukan secara luar biasa".

Bahkan Hoge Raad (Mahkamah Agung Belanda) dalam putusan perkara Cohen melawan Lindenbaum,

\footnotetext{
${ }^{42}$ A deterrent is something that prevents people from doing something by making them afraid of what will happen to them if they do it (lihat situs: http://dictionary.reverso.net/englishcobuild/deterrent\%20effect), band.: "deterrent effect" adalah efek yang membuat seseorang mengurungkan niatnya melakukan sesuatu karena takut akan ganjaran yang bakal ia terima (lihat situs: $\quad$ https://rubrikbahasa.wordpress.com/2010/09/24/ menggentarkan-malaysia/).

${ }^{43}$ Sanksi Sosial dan Hukum Korupsi (lihat situs: http://www. antikorupsi.org/id/content/sanksi-sosial-dan-hukum-korupsi).

${ }^{44}$ Republik Indonesia, Undang-Undang Nomor 7 Tahun 2006 tentang Pengesahan United Nation Convention Against Corruption, 2003 (Konvensi PBB Anti Korupsi, 2003), Penjelasan Bagian I Umum, Paragraf Pertama, (Lembaran Negara RI Tahun 2006 No. 32, Tambahan Lembaran Negara RI No. 4620).

${ }^{45}$ Op.Cit, Republik Indonesia, Undang-Undang Nomor 20 Tahun 2001, Bagian Menimbang, huruf a
} 
berpendapat bahwa perbuatan tercela adalah perbuatan melawan hukum yang selain melanggar hak subyektif orang lain, bertentangan dengan kewajiban hukum pelaku, juga bertentangan dengan kesusilaan yang baik dan kepatutan yang ada dalam masyarakat. Chairul Huda ${ }^{46}$ menyatakan: "pada dasarnya, tingkat ketercelaan suatu perbuatan, digambarkan dari makin berat jenis pidana dan makin banyak jumlah ancaman pidananya, maka akan makin dipandang tercela suatu perbuatan (serious)".

Dari uraian tersebut, maka perbuatan korupsi adalah perbuatan tercela karena selain melanggar hak subyektif orang lain, bertentangan dengan kewajiban hukum pelaku, juga bertentangan dengan kesusilaan yang baik dan kepatutan yang ada dalam masyarakat dan juga ancaman hukuman yang diperberat.

\section{Kesimpulan}

Pencabutan hak politik terpidana tindak pidana korupsi untuk selamanya, akan menjadi polemik. Menurut KUHPidana, pencabutan hak politik dapat dilakukan untuk tenggang waktu tertentu dengan putusan hakim. Padahal berdasarkan Pasal 28J ayat

(2) UUD 1945 dan Pasal 73 UU HAM, pembatasan atau pencabutan HAM hanya dapat dilakukan dengan undang-undang. Ternyata UU Tipikor di Indonesia tidakmengaturpencabutanhakpolitikterpidanatindak pidana korupsi untuk selamanya, tetapi mengacu pada ketentuan dalam KUHPidana. Berbeda dengan pencabutan hak politik seseorang yang melakukan perbuatan tercela, sebagaimana penjelasan Pasal 7 ayat (2) huruf i Undang-Undang Nomor 10 Tahun 2016. Untuk dapat melegalkan pencabutan hak politik terpidana korupsi untuk selamanya, maka perbuatan korupsi harus dikategorikan sebagai perbuatan tercela, karena secara filosofis, sosiologis dan yuridis dapat terpenuhi. Perbuatan korupsi adalah kebusukan, keburukan, kebejatan, ketidakjujuran, dapat disuap, tidak bermoral, penyimpangan dari kesucian dan merupakan ancaman terhadap prinsip-prinsip demokrasi yang menjunjung tinggi transparansi, akuntabilitas dan integritas.

Memang hal ini tidak akan mudah, karena mereka yang merasa hak politiknya tercabut akan berlindung di balik pandangan HAM yang menyatakan bahwa hak politik sebagai hak absolut yang tidak boleh dikurangi pemenuhannya oleh Negara, walau dalam keadaan darurat sekalipun serta di balik sistem pemasyarakatan di Indonesia yang menempatkan narapidana sebagai warga binaan yang kelak kembali ke masyarakat sebagai manusia yang baik dan bertanggung jawab, sebagaimana tujuan pemasyarakatan dalam UndangUndang tentang Pemasyarakatan.

\section{Saran}

Untuk dapat melegalkan pencabutan hak politik terpidana tindak pidana korupsi untuk selamanya, maka perbuatan korupsi harus dikategorikan sebagai perbuatan tercela. Oleh karena itu, penjelasan Pasal 7 ayat(2) hurufi Undang-Undang Nomor 10Tahun 2016, perlu diperluas maknanya menjadi: "yang dimaksud dengan melakukan perbuatan tercela antara lain: perbuatan korupsi, judi, mabuk, pemakai/pengedar narkotika, dan berzina, serta perbuatan melanggar kesusilaan lainnya". Demikian juga, jika nantinya dibuat undang-undang yang baru terkait kontestasi politik (pemilihan), maka perbuatan korupsi harus dikategorikan sebagai perbuatan tercela.

\footnotetext{
${ }^{46}$ Republik Indonesia, Putusan Mahkamah Konstitusi Nomor: 42/ PUU-XIII/2015, hal. 39, paragraph ke-2.
} 


\section{Daftar Pustaka}

Al Quran

Alkitab

\section{Buku}

Andi Hamzah, Pemberantasan Korupsi: Melalui Hukum Pidana Nasional dan Internasional, Jakarta: Rajawali Pers, 2014.

A. Gunawan Setiardja, Hak-Hak Asasi Manusia Berdasarkan Ideologi Pancasila, Yogyakarta: Kanisius, 1993. P.A.F.Lamintang dan Theo Lamintang, Hukum Penitensier Indonesia, Jakarta: Sinar Grafika,2010.

Ruslan Renggong, Hukum Pidana Khusus: Memahami Delik-delik di luar KUHP, Jakarta: Prenadamedia Group, 2016.

Sudarto, Hukum dan Hukum Pidana, Bandung: Alumni, 2007.

\section{Aturan Hukum}

Pancasila.

Undang-Undang Dasar Negara RI 1945. Kitab Undang-Undang Hukum Pidana.

International Convenant on Civil and Political Rights.

Undang-Undang RI Nomor 10 Tahun 2016 tentang Perubahan Kedua Atas Undang-Undang Nomor

1 Tahun 2015 tentang Penetapan Peraturan Pemerintah Pengganti Undang-Undang Nomor

1 Tahun 2014 tentang Pemilihan Gubernur, Bupati, Dan Walikota Menjadi Undang-Undang, (Lembaran Negara RI Tahun 2016 No. 130, Tambahan Lembaran Negara RI No. 5898).

Undang-Undang RI Nomor 7 Tahun 2006 tentang Pengesahan United Nation Convention Against Corruption, 2003 (Konvensi PBB Anti Korupsi, 2003), (Lembaran Negara RI Tahun 2006 No. 32, Tambahan Lembaran Negara RI No. 4620).

Undang-Undang RI Nomor 20 Tahun 2001 tentang Perubahan Atas Undang-Undang Nomor 31 Tahun 1999 tentang Pemberantasan Tindak Pidana Korupsi, (Lembaran Negara RI Tahun 2001 No. 134, Tambahan Lembaran Negara RI No. 4150).

Undang-Undang RI Nomor 39 Tahun 1999 tentang Hak Asasi Manusia, (Lembaran Negara RI Tahun 1999 No. 165, Tambahan Lembaran Negara RI No. 3886).

Undang-Undang RI Nomor 31 Tahun 1999 tentang Pemberantasan Tindak Pidana Korupsi, (Lembaran Negara RI Tahun 1999 No. 140, Tambahan Lembaran Negara RI No. 3874).

Undang-Undang RI Nomor 12 Tahun 1995 tentang Pemasyarakatan, (Lembaran Negara RI Tahun 1995 No. 77, Tambahan Lembaran Negara RI No. 3614).

Putusan Mahkamah Konstitusi RI Nomor: 42/PUU- XIII/2015.

\section{Artikel}

Hamdan Zoelva, Fenomena Korupsi di Indonesia dari Sudut Pandang Filsafat Ilmu, https:// hamdanzoelva.wordpress.com/2008/08/1 1/ fenomena-korupsi-dari-sudut-pandang-filsafat-ilmu/.

Hammady Ghitsny, Pandangan Agama terhadap Korupsi, http://www.kompasiana.com/ hammady/pandangan-agama-terhadap-korupsi_58b28624147b61fa10260673.

Ifdhal Kasim (Editor), Hak Sipil dan Politik Esai-Esai Pilihan, Jakarta: Lembaga Studi dan Advokasi Masyarakat (ELSAM), 2001.

Muhardi Hasan dan Estika Sari, Hak Sipil dan Politik, Demokrasi, Vol. IV No.1 th. 2005, http://ejournal.unp.ac.id/index.php/jd/article/ viewFile/1001/843.

Sigid Suseno, Pungli/ Gratifikasi/ Penyalahgunaan Jabatan = Korupsi, Bahan Pendidikan Anti Korupsi:Bandung, 2016.

Soumy Mubarok dan Lismanto, Korupsi sebagai Perbuatan Khiyanat dalam Hukum Islam, http:// www.islamcendekia.com/2014/01/korupsi- sebagai-perbuatan-khiyanat-dalam-hukum-islam.html? $m=1$. 
Vita Dwi Sakundiana, Pencabutan Hak Politik Bagi Koruptor, https://safwaalmahyra.wordpress. com/2016/12/27/pencabutan-hak-politik-bagi-koruptor/.

YonMaryono,Dimensi Korupsidalam Alkitab, http://artikel.sabda.org/dimensi_korupsi_dalam_alkitab.

Internet

www.antaranews.com/print/104149/kpk-pancasila-sumber-nilai-anti-korupsi.

www.antikorupsi.org/id/content/sanksi-sosial-dan-hukum-korupsi.

www.bisnis.liputan6.com/read/2469051/10-negara-dengan-pendapatan-tertinggi-di-asia.

www.dosenekonomi.com/ilmu-ekonomi/publik/faktor-pembangunan-ekonomi.

www.dictionary.reverso.net/english-cobuild/ deterrent\%20effect.

www.ekonomikontekstual.com/2014/04/4-faktor- yang-memengaruhi-pertumbuhan-dan- pembangunan ekonomi.html.

kbbi.web.id

www.rubrikbahasa.wordpress.com/2010/09/24/ menggentarkan-malaysia/ 

